\title{
Refurbishment and electrification in the hotel sector: four hotels in the historic centre of Rome
}

\author{
Giada Romano $^{\mathrm{a}, 1^{*}}$ and Francesco Mancini ${ }^{\mathrm{a}}$ \\ ${ }^{a}$ Department of Planning, Design and Technology of Architecture, Sapienza University of Rome, Via Flaminia 72, 00196 \\ Rome, Italy
}

\begin{abstract}
According to the European Renovation Wave, the European building stock is obsolete and changes very slowly: more than 220 million housing units and $85-95 \%$ of the existing buildings will still be in use in 2050 and are absolutely not energy efficient. To cut emissions by $55 \%$ by 2030 , the EU should reduce greenhouse gas emissions from buildings by $60 \%$, their final energy consumption by $14 \%$ and energy consumption for heating and cooling by $18 \%$. It is therefore urgent for the EU to focus on making buildings more energy efficient, less carbon intensive throughout their life cycle and more sustainable. From this framework comes the need for an adaptation not only of residential buildings but also of hotel facilities, which, on a national scale, make up about $45 \%$ of the accommodation facilities. In particular, the offer of accommodation facilities must be constantly adequate and the structures must be upgraded so that they always remain usable and comply with current regulations from the accessibility, seismic-structural and energy point of view. In this research, four hotels located in the historic centre of Rome have been analysed as case studies. Starting from an analysis of the current state, a series of interventions on the building envelope and systems have been studied, evaluating energy savings and the reduction of polluting emissions. With regard to the systems, the total electrification of the heating and domestic hot water preparation systems has been hypothesised, with the introduction of storage systems, also in view of participation in Demand Response programs.
\end{abstract}

\section{Introduction}

The generation of electricity in Italy and in the rest of Europe has traditionally been entrusted to a centralized production system, with a mix of different power plants and different sources, renewable and non-renewable [12], but this must be adequate and made more efficient in light of the standards imposed by the European Commission for the drastic reduction of energy consumption [ $\underline{3}-\underline{4}]$.

The Italian electricity system has always been characterized by the widespread use of hydroelectric systems [5]; since 2006, these systems have been joined by numerous other plants powered by renewable energy sources (RES), especially photovoltaic, wind and thermoelectric plants powered by bioenergy [6]. In 2019, the RES share of total energy consumption reached $18.2 \%$ in Italy, of which $35 \%$ in the electricity sector and $19.7 \%$ in the thermal sector. The demand for Italian electricity was largely offset by national production with imports of between $10-15 \%$ of the total [7]. The main problem of our national electricity system is not in terms of energy, but above all in terms of power: the national electricity system has a demand for power ranging between 20-25 GW at night and 40-60 GW during daytime [ $\underline{8}-9]$. It is evident that if the RES produced continuously they could almost completely cover the demand for electrical power, but this is very far from reality for reasons that vary from the technology of the system, to the primary source used or to other exogenous conditions that cannot be controlled and difficult to predict. [10]. During the mid-seasons, when there is no consumption for air conditioning, there is a situation of overproduction due to the technical impossibility of blocking thermoelectric production for an interval of a few hours [11]. This situation in the years to come will tend to worsen in step with climate change [12-13] both due to an increasingly conspicuous increase in the installation of photovoltaic and wind systems, and to the increase in energy efficiency measures that will tend to increase further periods of overproduction [14]. The costs of electricity will be affected, in particular for the ratio between produced energy and consumed energy, which affects costs during the day [10]. For these reasons it is important to arrive at a more efficient management of energy accumulations and a lower differentiation of energy prices between the different time bands of the day and for this to happen it is useful to envisage that each user can participate in a Demand Response activity [15]. The figure of an "aggregator", which facilitates consumers to provide flexibility on their electricity demand, is necessary for all sectors ranging from residential to hospitality.

2019 counted 131.4 million arrivals in Italy, 436.7 million presences and a growth of $2.6 \%$ in the tourism sector compared to the previous year [16]. According to the ENIT report, before the pandemic it accounted for about 13\% of the Gross Domestic Product [17]. In Italy in February 2020 there were about 33 thousand hotels, for over 2.23 million beds, and 183 thousand non-hotel establishments. The numbers for the sector have been growing steadily from 2010 until just before the pandemic crisis. In 2019 the expenditure of international tourism

\footnotetext{
${ }^{1 *}$ Corresponding author: giada.romano@uniroma1.it
} 
had grown by $6.6 \%$ and there was an increase in overnight stays of $4.4 \%$ [16], while the expenditure for consumption deriving from plant systems covered about $35 \%$ of the costs of total management [18].

Businesses in the tourism sector must constantly adapt their offer, in order to respond effectively to the ever new demands of tourists, to seize all the opportunities connected with the development of markets and to react promptly to economic changes [19]. The hospitality sector, in particular, needs continuous investments to upgrade the facilities and make them competitive on the market [20].

The research has been developed starting from an analysis of 500 hotels sampled throughout the country to evaluate the percentages of incidence in the climatic zones, the stars rating based on the definition given by the DPCM 21/10/2008 [21], the months of opening, the number of rooms and the generation systems for domestic hot water and heating. This analysis has led to the definition of the criteria necessary for the selection of the structures to be investigated.

\section{Analysis of the building features}

The four buildings selected for the in-depth study are located in the climatic zone D, more precisely in the historic centre of the city of Rome. They are 3-star hotel structures with a number of rooms between 18 and 55 rooms, all equipped with terminals for heating or cooling, TV and small appliances.

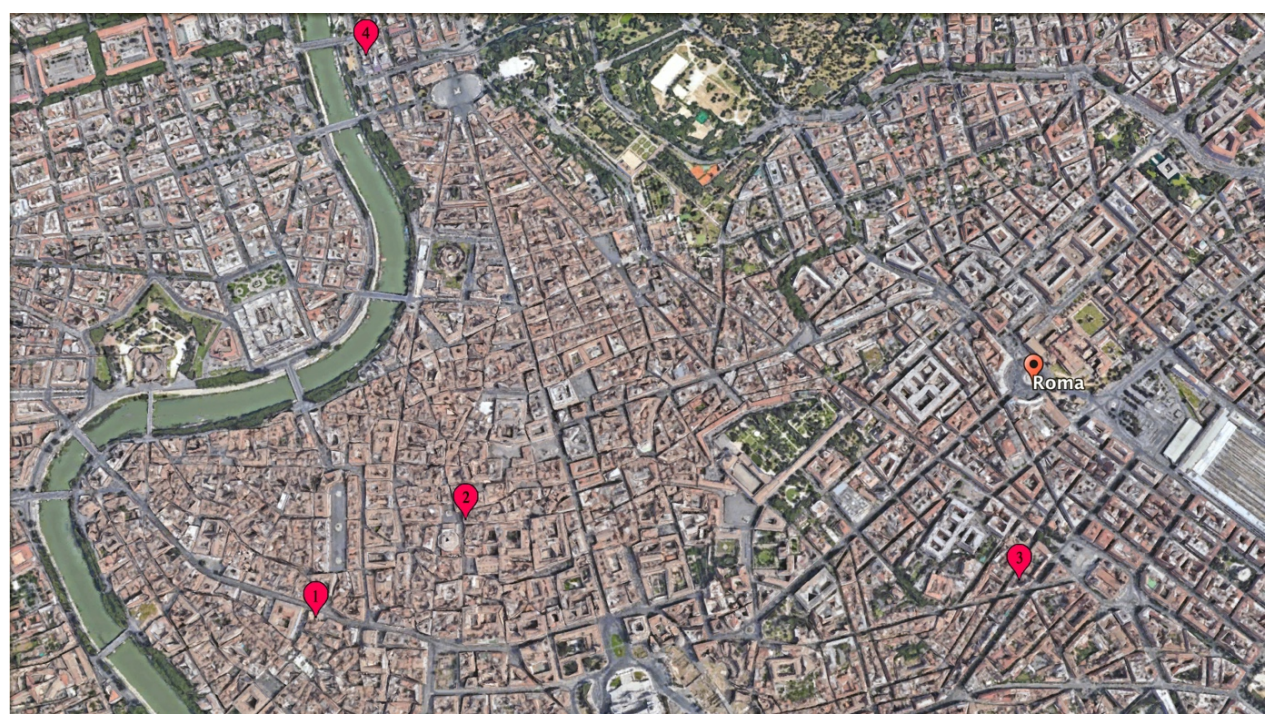

Fig. 1. The four hotels in the centre of Rome. Case study n.1 is the Hotel Damaso; case study n.2 is the Hotel Albergo del Senato; case study n. 3 is the Hotel Raffaello; case study n.4 is the Albergo Etico.

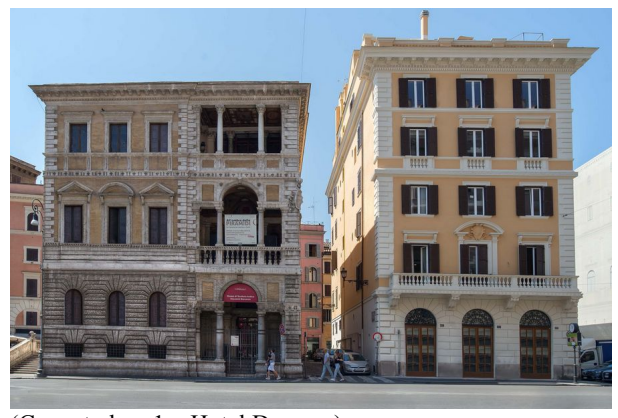

(Case study n.1 - Hotel Damaso)



(Case study n.2 - Hotel Albergo del Senato) 


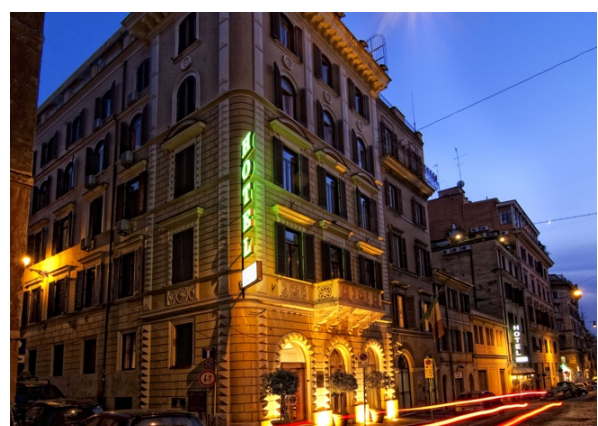

(Case study n.3 - Hotel Raffaello)

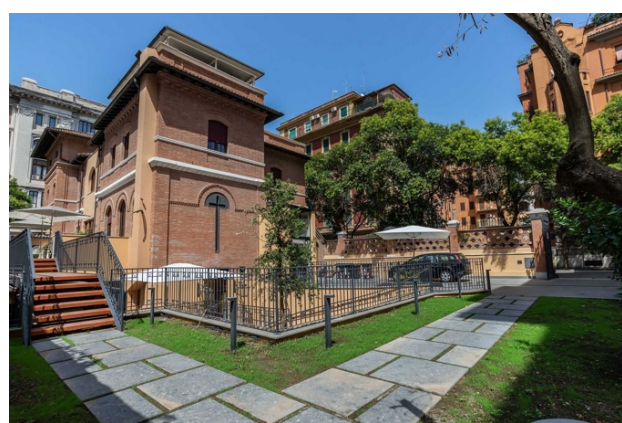

(Case study n.4 - Albergo Etico)

Fig. 2. The four hotels in the centre of Rome.

All four hotels are virtuous examples of renovation of historic buildings.

Hotel Damaso (case study number 1 in the previous picture and following tables) housed in a completely restored nineteenth century palace, it is a superior 3 -star hotel and hosts 39 rooms, its surface is of $1,320 \mathrm{~m}^{2}$ while the volume is $3,960 \mathrm{~m}^{3}$ given the average height of the floors of $3.0 \mathrm{~m}$; the glazed surface is $215 \mathrm{~m}^{2}$ and the ratio between the glazed surface and the opaque surface is 0.163. The 3-star Hotel Albergo del Senato (case study number 2 in the previous picture and following tables) is located in the city centre of Rome and occupies a building that dates back to 19th century and was designed by the talented Italian architect Gaetano Koch: it has 55 rooms, an area of $2,154 \mathrm{~m}^{2}$, an average height of $3.0 \mathrm{~m}$ per floor and consequently a volume of $6,462 \mathrm{~m}^{3}$; the glazed surface is $222 \mathrm{~m}^{2}$ and the ratio between the glazed surface and the opaque surface is 0.103 . The Hotel Raffaello (case study number 3 in the previous picture and following tables) is a 3-Star hotel with 41 rooms, it has an area of $1,471 \mathrm{~m}^{2}$, an average height of $3.1 \mathrm{~m}$ per floor and consequently a volume of $4,560 \mathrm{~m}^{3}$; the glazed surface is $155 \mathrm{~m}^{2}$ and the ratio between the glazed surface and the opaque surface is 0.105 . The northernmost building of the four in the City, is an ancient building of the twentieth century, it was renovated and nowadays hosts the Albergo Etico (case study number 4 in the previous picture and following tables). The hotel houses 18 rooms. The hotel has an area of $1,464 \mathrm{~m}^{2}$ with an average floor height of $4.0 \mathrm{~m}$ and a total volume of $5,800 \mathrm{~m}^{3}$; the glazed surface is $150 \mathrm{~m}^{2}$ and the ratio between the glazed surface and the opaque surface is 0.193 .

Table 1. Geometric data of the four buildings

\begin{tabular}{cccccc}
\hline & & Case study n.1 & Case study n.2 & Case study n.3 & Case study n.4 \\
\hline Opaque surface & {$\left[\mathrm{m}^{2}\right]$} & 1,320 & 2,154 & 1,471 & 1,464 \\
Glazed surface & {$\left[\mathrm{m}^{2}\right]$} & 215 & 222 & 155 & 150 \\
Surface/Volume ratio & & 0.388 & 0.368 & 0.357 & 0.341 \\
Average height & {$[\mathrm{m}]$} & 3.0 & 3.0 & 3.10 & 4.0 \\
Volume & {$\left[\mathrm{m}^{3}\right]$} & 3,960 & 6,462 & 4,560 & 5,800 \\
\hline
\end{tabular}

The building envelope of the buildings has been analysed and measured to evaluate their behaviour in terms of temperature and pressure trends inside. These analyses also made it possible to carry out the Glazer verification to understand whether or not condensation was present within the wall thicknesses. Below is an example of the analysis carried out on the building envelope in case study n. 1 Hotel Damaso for the external perimeter walls (Fig. 3).

In all four cases, similar by construction period, the opaque envelope is mainly made of mixed stone and brick masonry with a variable thickness: case study n.1 Hotel Damaso presents two types of opaque perimeter walls of different thicknesses, the thinnest of $44 \mathrm{~cm}$ and the thickest of $83 \mathrm{~cm}$ with a U-value of respectively of 1.742 $\mathrm{W} / \mathrm{m}^{2} \mathrm{~K}$ and of $1.102 \mathrm{~W} / \mathrm{m}^{2} \mathrm{~K}$. 
EXTERNAL PERIMETER WALL $1\left(R=0,908\right.$ and $\left.U=1,102 \mathrm{~W} / \mathrm{m}^{2} \mathrm{~K}\right)$

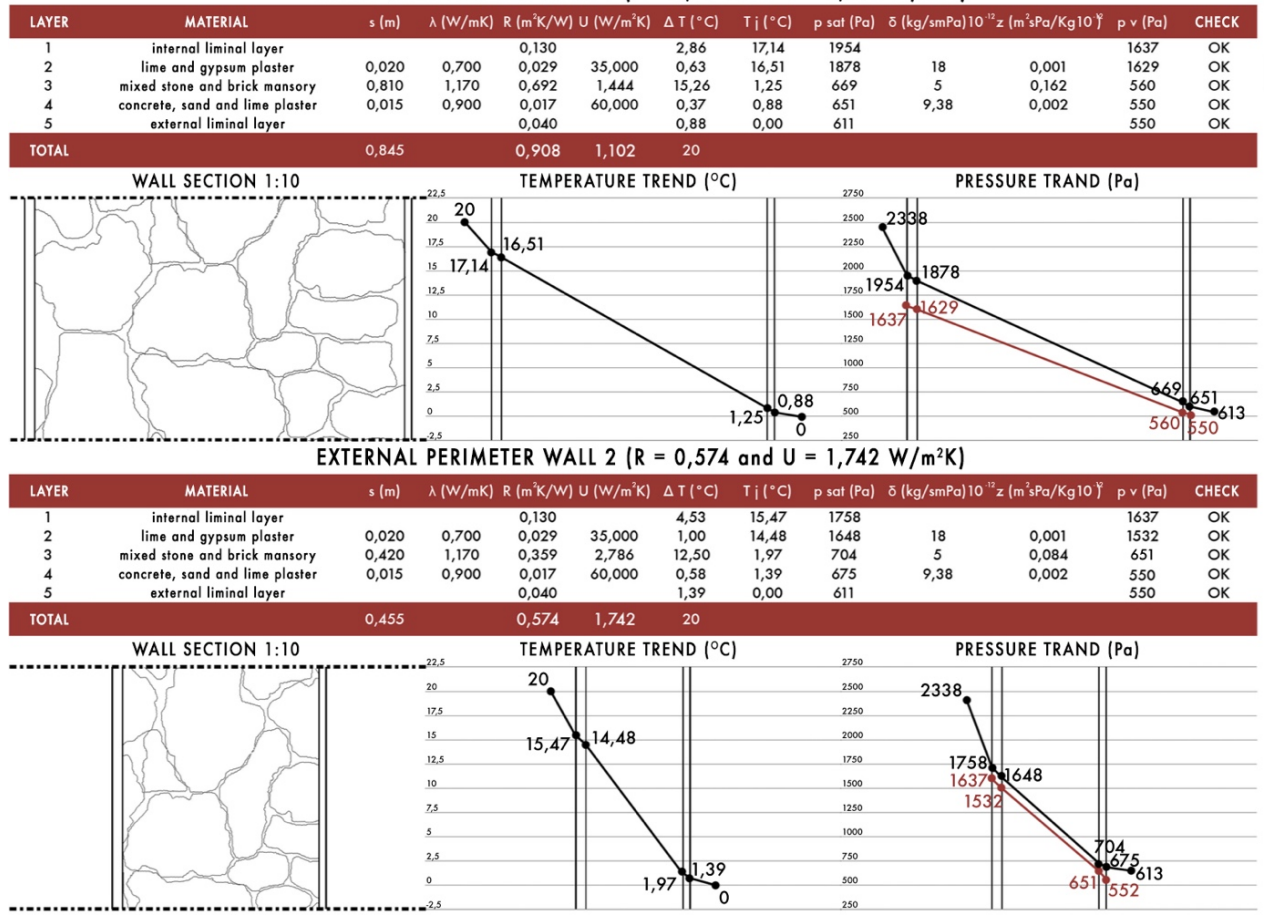

Fig. 3. Example of analysis of the building envelope, external walls of the case study n.1 - Hotel Damaso. Wall sections, Uvalue calculation, Glazer check and temperature and pressure trend evaluation.

The case study n.2 Hotel Albergo del Senato also has two different thicknesses for the external perimeter walls of $44 \mathrm{~cm}$ and $57 \mathrm{~cm}$ with a U-value of respectively $1.742 \mathrm{~W} / \mathrm{m}^{2} \mathrm{~K}$ and of $1.459 \mathrm{~W} / \mathrm{m}^{2} \mathrm{~K}$; the Hotel Raffaello, case study n. 3 varies from a thickness of $22 \mathrm{~cm}$ to a thickness of $57 \mathrm{~cm}$ with the $\mathrm{U}$-value of $1.877 \mathrm{~W} / \mathrm{m}^{2} \mathrm{~K}$ and of 1.459 $\mathrm{W} / \mathrm{m}^{2} \mathrm{~K}$; the Albergo Etico, case study n.4, also has two different thicknesses for the external perimeter walls of $30 \mathrm{~cm}$ and $66 \mathrm{~cm}$ with a $\mathrm{U}$-value of $1.798 \mathrm{~W} / \mathrm{m}^{2} \mathrm{~K}$ and of $1.373 \mathrm{~W} / \mathrm{m}^{2} \mathrm{~K}$.

For horizontal surfaces, the ground and roof floors are of the predalles type with a concrete slab and ceramic or marble tile finish for the ground floor, depending on the case study, with an average thickness of $32-35 \mathrm{~cm}$ and a U-value of $1.986 \mathrm{~W} / \mathrm{m}^{2} \mathrm{~K}$ and $2.032 \mathrm{~W} / \mathrm{m}^{2} \mathrm{~K}$. The glazed surfaces in the first three case studies all resulted in 46-4 double glazing with wooden frame and a transmittance of $3.115 \mathrm{~W} / \mathrm{m}^{2} \mathrm{~K}$ while in the case study n. 4 - Albergo Etico the fixtures are single-glazed with wooden frame and $\mathrm{U}$-value equal to $5 \mathrm{~W} / \mathrm{m}^{2} \mathrm{~K}$.

Table 2. Thickness $[\mathrm{cm}]$ and $\mathrm{U}$-values $\left[\mathrm{W} / \mathrm{m}^{2} \mathrm{~K}\right]$ of opaque and glazed building components for each case study.

\begin{tabular}{lcccccccc}
\hline & \multicolumn{2}{c}{ Case study n.1 } & \multicolumn{2}{c}{ Case study n.2 } & \multicolumn{2}{c}{ Case study n.3 } & \multicolumn{2}{c}{ Case study n.4 } \\
\hline & $\begin{array}{c}\text { Thickness } \\
{[\mathrm{cm}]}\end{array}$ & $\begin{array}{c}\text { U-value } \\
{\left[\mathrm{W} / \mathrm{m}^{2} \mathrm{~K}\right]}\end{array}$ & $\begin{array}{c}\text { Thickness } \\
{[\mathrm{cm}]}\end{array}$ & $\begin{array}{c}\mathrm{U} \text {-value } \\
{\left[\mathrm{W} / \mathrm{m}^{2} \mathrm{~K}\right]}\end{array}$ & $\begin{array}{c}\text { Thickness } \\
{[\mathrm{cm}]}\end{array}$ & $\begin{array}{c}\text { U-value } \\
{\left[\mathrm{W} / \mathrm{m}^{2} \mathrm{~K}\right]}\end{array}$ & $\begin{array}{c}\text { Thickness } \\
{[\mathrm{cm}]}\end{array}$ & $\begin{array}{c}\text { U-value } \\
{\left[\mathrm{W} / \mathrm{m}^{2} \mathrm{~K}\right]}\end{array}$ \\
Bearing Wall 1 & 44 & 1.742 & 44 & 1.742 & 22 & 1.877 & 30 & 1.798 \\
Bearing Wall 2 & 83 & 1.102 & 57 & 1.459 & 57 & 1.459 & 66 & 1.373 \\
Ground floor & 35 & 2.023 & 35 & 2.023 & 35 & 2.023 & 35 & 2.023 \\
Roof & 32 & 1.986 & 32 & 1.986 & 32 & 1.986 & 32 & 1.986 \\
Windows & 1,5 & 3.115 & 1,5 & 3.115 & 1,5 & 3.115 & 1.5 & 5 \\
\hline
\end{tabular}


The next phase after the analysis of the building envelope has been concentrated on the analysis of the thermal loads (winter and summer) of the four buildings sampled for the research.

From the point of view of thermal loads for the case study n.1 Hotel Damaso an overall consumption equal to $490,720 \mathrm{kWh} / \mathrm{y}$ of non-deferrable thermal loads has been detected [loads due to lighting (57\%), transport of people or things $(1 \%)$, various electrical uses $(9 \%)$, heating $(16 \%)$ and production of domestic hot water $(17 \%)]$ and an annual consumption of $4,526 \mathrm{kWh} / \mathrm{y}$ of deferrable thermal loads (loads depending on washing machine, dishwasher, dryer).

Case study n.2 Hotel Albergo del Senato shows an annual consumption of 503,974 kWh/y of non-deferrable thermal loads (of which $28 \%$ due to lighting, $1 \%$ due to the transport of people or things, $9 \%$ linked to various electrical uses, $18 \%$ to heating, $16 \%$ to cooling and $27 \%$ for the production of domestic hot water); from the point of view of deferrable thermal loads, in this case the share is equal to $4,935 \mathrm{kWh} / \mathrm{y}$.

Case study n.3, the Raffaello Hotel, has an annual consumption of 306,193 kWh/y from the point of view of non-deferrable thermal loads [loads divided between lighting $(35 \%)$, transport of people or things $(1 \%)$, various types of electricity $(13 \%)$, heating $(20 \%)$ and production of domestic hot water $(30 \%)$ ] while as regards the deferrable loads, the annual consumption is equal to $4,274 \mathrm{kWh} / \mathrm{y}$.

Case study n.4, the Albergo Etico has an annual consumption of $325,222 \mathrm{kWh} / \mathrm{y}$ (of which $42 \%$ for lighting, $1 \%$ for the transport of people or things, $10 \%$ for various electrical uses, $16 \%$ for heating, $14 \%$ both for cooling and for the production of sanitary water and 3\% for mechanical ventilation) from the point of view of nondeferrable thermal loads and $4,155 \mathrm{kWh} / \mathrm{y}$ for deferrable thermal loads.

Table 3. Deferrable and non-deferrable loads year consumption for each case study.

\begin{tabular}{lccccc}
\hline & & Case study n.1 & Case study n.2 & Case study n.3 & Case study n.4 \\
\hline Non-deferrable loads & {$[\mathrm{kWh} /$ year $]$} & 490,720 & 503,974 & 306,193 & 325,222 \\
Deferrable loads & {$[\mathrm{kWh} /$ year $]$} & 4,526 & 4,935 & 4,274 & 4,155 \\
Deferrable Fraction & {$[\%]$} & 0.92 & 0.98 & 1.40 & 2.023 \\
& & & & \\
\hline
\end{tabular}


Fig. 4. Graph of the annual consumption of non-deferrable loads for each case study. Percentage share of lighting, transport of people or things, various electrical uses, heating, cooling, domestic hot water production and mechanical ventilation. Top left case study n.1, top right case study n.2, bottom left case study n.3, bottom right case study n.4.

In all four hotels, the presence of heat generators powered by methane gas and radiators as terminals for the heating supply to the rooms has been found. 
Looking at the information collected, it has been possible to make a calculation of the primary energy consumption for each case study which is explained in Table 4(a-d).

Table 4a. Primary energy consumption - before interventions for the case study n.1 - Hotel Damaso

\begin{tabular}{lccccccc}
\hline & & Heating & Cooling & Hot water & Lifts & Lighting & Total \\
\hline Renewable & {$[\mathrm{kWh} / \mathrm{y}]$} & 0 & 0 & 0 & 3,301 & 67,472 & 70,773 \\
Fossil & {$[\mathrm{kWh} / \mathrm{y}]$} & 79,092 & 0 & 83,977 & 3,301 & 280,057 & 445,635 \\
Total & {$[\mathrm{kWh} / \mathrm{y}]$} & 79,092 & 0 & 83,977 & 6,602 & 347,529 & 516,408 \\
Renewable fraction & $\%$ & $0 \%$ & $0 \%$ & $0 \%$ & $50 \%$ & $19.4 \%$ & $13.7 \%$ \\
\hline
\end{tabular}

Table 4b. Primary energy consumption - before interventions for the case study n. 2 - Hotel Albergo del Senato

\begin{tabular}{lccccccc}
\hline & & Heating & Cooling & Hot water & Lifts & Lighting & Total \\
\hline Renewable & {$[\mathrm{kWh} / \mathrm{y}]$} & 0 & 15,946 & 0 & 0,839 & 27,277 & 44,062 \\
Fossil & {$[\mathrm{kWh} / \mathrm{y}]$} & 92,531 & 66,513 & 139,740 & 3,357 & 113,513 & 415,444 \\
Total & {$[\mathrm{kWh} / \mathrm{y}]$} & 92,531 & 82,459 & 139,740 & 4,196 & 140,790 & 459,506 \\
Renewable fraction & $\%$ & $0 \%$ & $19.3 \%$ & $0 \%$ & $20 \%$ & $19.4 \%$ & $9.6 \%$ \\
\hline
\end{tabular}

Table 4c. Primary energy consumption - before interventions for the case study n. 3 - Hotel Raffaello

\begin{tabular}{lccccccc}
\hline & & Heating & Cooling & Hot water & Lifts & Lighting & Total \\
\hline Renewable & {$[\mathrm{kWh} / \mathrm{y}]$} & 0 & 0 & 0 & 0,878 & 20,931 & 21,809 \\
Fossil & {$[\mathrm{kWh} / \mathrm{y}]$} & 61,036 & 0 & 92,652 & 3,367 & 87,090 & 244,584 \\
Total & {$[\mathrm{kWh} / \mathrm{y}]$} & 61,036 & 0 & 92,652 & 4,245 & 108,021 & 266,393 \\
Renewable fraction & $\%$ & $0 \%$ & $0 \%$ & $0 \%$ & $20 \%$ & $19.4 \%$ & $8.2 \%$ \\
\hline
\end{tabular}

Table 4d. Primary energy consumption - before interventions for the case study n.4 - Albergo Etico

\begin{tabular}{lccccccc}
\hline & & Heating & Cooling & Hot water & Lifts & Lighting & Total \\
\hline Renewable & {$[\mathrm{kWh} / \mathrm{y}]$} & 0 & 8,305 & 0 & 1,305 & 25,908 & 35,518 \\
Fossil & {$[\mathrm{kWh} / \mathrm{y}]$} & 49,692 & 35,179 & 62,115 & 4,907 & 107,640 & 275,059 \\
Total & {$[\mathrm{kWh} / \mathrm{y}]$} & 49,692 & 43,481 & 62,115 & 6,212 & 133,548 & 310,577 \\
Renewable fraction & $\%$ & $0 \%$ & $19.1 \%$ & $0 \%$ & $21 \%$ & $19.4 \%$ & $11.4 \%$ \\
\hline
\end{tabular}

\section{Materials and Methods}

Having gathered all the information, useful for the in-depth study of the four buildings studied, first of all in-situ surveys have been carried out which made it possible to collect the geometric data relating to the structures, the dispersing surfaces, the building envelope and the systems. The calculations of the thermal loads and the storability of the loads have been then made [15-24], based on the evaluation made on the periods of opening and 
occupation of the hotels during the year and finally the calculation of the energy requirements has been carried out through the use of specific software according to the methods described in [22-23].

Having collected all the data, it has been possible to determine for each case study the global consumption of non-renewable energy $\left(\mathrm{Ep}_{\mathrm{gl}, \text {,nren }}\right)$, the energy class to which it belongs and the energy performance of the buildings in summer and winter: for the case study n. 1 Hotel Damaso, $E p_{\text {gl, nren }}$ is equal to $337.5 \mathrm{kWh} / \mathrm{m}^{2} \mathrm{y}$ and the energy class is $\mathrm{E}$ with a low quality winter and summer performance of the building; for the case study n.2 Hotel Albergo del Senato, the E $p_{\mathrm{gl}, \text { nren }}$ is equal to $198.0 \mathrm{kWh} / \mathrm{m}^{2} \mathrm{y}$ and the energy class is $\mathrm{D}$ with a low-quality winter and summer performance of the building; for the case study n. 3 Hotel Raffaello, Ep $p_{\mathrm{gl}, \mathrm{nren}}$ is equal to $167.1 \mathrm{kWh} / \mathrm{m}^{2} \mathrm{y}$ and the energy class is D with a low-quality winter and summer performance of the building; for the case study n.4 Albergo Etico, Ep $p_{\mathrm{gl}, \mathrm{nren}}$ is equal to $274.6 \mathrm{kWh} / \mathrm{m}^{2} \mathrm{y}$ and the energy class is $\mathrm{E}$ with a low-quality winter and summer performance of the building.

The next phase, from a methodological point of view, involved determining the interventions based on various aspects: the first interventions to be determined have been those of energy refurbishment, divided between interventions on the building envelope and those on the systems; a cost-benefit analysis has been then carried out with an in-depth study of the incentive tools at the state and regional level available to finance the interventions necessary for the improvement; finally, a new calculation of the energy requirements and the storability of the loads have been repeated to evaluate the benefits achieved from an energy and economic point of view.

\section{Intervention strategies and results}

Having collected all the necessary information related to the status quo of the four buildings, it has been possible to make conscious considerations that have led to the determination of the intervention objectives common to all four case studies. The first objective, the reduction of consumption, has been defined to allow significant energy and, therefore, economic savings; the second objective linked to the increase in thermo-hygrometric well-being is essential to improve the quality of the service offered by hotels; the third, and last, objective is the total electrification of the users, to reduce $\mathrm{CO}_{2}$ emissions and to have storable loads available that can be managed by electricity aggregators.

Starting from the objectives, a series of intervention strategies have been formulated, divided between interventions on the building envelope and interventions on the systems (heating and cooling, domestic hot water production, ventilation, lighting and PV integration).

The strategies have been then divided into the following design solutions.

For the building envelope the choice has been to:

1. Insert a layer of internal insulation both in the vertical and horizontal structures in expanded polyethylene (with closed cells);

2. Replace the existing windows with 4-12-4 double-glazed windows, maintaining the choice of the wooden frame.

For the systems it has been chosen to:

1. Intervene on the heating and cooling system by installing heat pumps and fan coils for both winter and summer air conditioning;

2. Intervene on the domestic hot water production system by slaving it to heat pumps;

3. Install a mechanical ventilation system equipped with a heat recovery unit;

4. Replace existing lamps with LED lamps and insert motion and presence sensors in common areas and hallways for the lighting system;

5. Integrate the PV panels on the roof.

Referring to the building envelope, since these are buildings in the historic centre and therefore bound to the non-modification of the façades, it has been decided to insert a layer of closed-cell expanded polyethylene insulation in the internal layer to obtain higher thermal performances. This insulating layer has a thermal resistance of $2.38 \mathrm{~m}^{2} \mathrm{~K} / \mathrm{W}$ and a thermal conductivity at $10^{\circ} \mathrm{C}$ of $0.015 \mathrm{~W} / \mathrm{mK}$ for a thickness of $50 \mathrm{~mm}$, can resist to water and to high temperature up to $210^{\circ} \mathrm{C}$.

For glazed surfaces, in all the four hotels, it has been decided to replace old wooden windows with new ones. Wooden frames have always been chosen, so as not to alter the aesthetics of the façades, but with 4-12-4 double glazing and a transmittance of $2.8 \mathrm{~W} / \mathrm{m}^{2} \mathrm{~K}$. 
Table 5. Comparison between the U-values $\left[\mathrm{W} / \mathrm{m}^{2} \mathrm{~K}\right]$ of opaque and glazed building components before and after the intervention on the building envelope for each case study.

\begin{tabular}{lcccccccc}
\hline & \multicolumn{2}{c}{ Case study n.1 } & \multicolumn{2}{c}{ Case study n.2 } & \multicolumn{2}{c}{ Case study $\mathrm{n} .3$} & \multicolumn{2}{c}{ Case study n.4 } \\
\hline & \multicolumn{2}{c}{ U-value $\left[\mathrm{W} / \mathrm{m}^{2} \mathrm{~K}\right]$} & \multicolumn{2}{c}{$\mathrm{U}$-value $\left[\mathrm{W} / \mathrm{m}^{2} \mathrm{~K}\right]$} & \multicolumn{2}{c}{$\mathrm{U}$-value $\left[\mathrm{W} / \mathrm{m}^{2} \mathrm{~K}\right]$} & \multicolumn{2}{c}{ U-value $\left[\mathrm{W} / \mathrm{m}^{2} \mathrm{~K}\right]$} \\
before & after & \multicolumn{2}{c}{ before } & after & before & after & before & after \\
Bearing Wall 1 & 1.742 & 0.329 & 1.742 & 0.329 & 1.877 & 0.331 & 1.798 & 0.327 \\
Bearing Wall 2 & 1.102 & 0.317 & 1.459 & 0.338 & 1.459 & 0.338 & 1.373 & 0.321 \\
Ground floor & 2.023 & 0.348 & 2.023 & 0.348 & 2.023 & 0.348 & 2.023 & 0.348 \\
Roof & 1.986 & 0.342 & 1.986 & 0.342 & 1.986 & 0.342 & 1.986 & 0.342 \\
Windows & 3.115 & 2.785 & 3.115 & 2.785 & 3.115 & 2.785 & 5 & 2.785 \\
\hline
\end{tabular}

As regards the systems related to heating and cooling, production of domestic hot water, and mechanical ventilation, the choice common to all buildings has been to install a variable number of cases in the case of fan coils with thermal power between 2 and $2.06 \mathrm{~kW}$ and cooling capacity between 1.1 and $1.38 \mathrm{~kW}$ as supply terminals, while as regards the heat recovery units, also in varying numbers depending on the case studies, those with an air flow rate have been chosen variable nominal between 1,500 and 3,000 $\mathrm{m}^{3} / \mathrm{h}$ and an efficiency of $70 \%$; To transition heating, buildings must break away from fossils fuels and increase efficiency, so that the heat pumps have been installed everywhere and they have been sized from time to time for each case study with variable performance and coefficients of efficiency. For the case study n. 1 it has been proposed the installation of two heat pumps (heating performance of $55 \mathrm{~kW}$ with $\mathrm{COP}=3.8$ and cooling performance of $47 \mathrm{~kW}$ with EER $=3.4$ ), 42 fan coils and three heat recovery units; in the case study n.2, two heat pumps have been installed (one with heating performance of $65 \mathrm{~kW}$ with $\mathrm{COP}=3.8$ and cooling performance of $55 \mathrm{~kW}$ with EER $=3.4$ and the other with heating performance of $120 \mathrm{~kW}$ with $\mathrm{COP}=3.9$ and cooling performance of $93 \mathrm{~kW}$ with EER $=3.3$ ), 61 fan coils and four heat recovery units; in case studies 3 and 4, as in the first case study, two heat pumps have been installed with heating performance of $55 \mathrm{~kW}$ with $\mathrm{COP}=3.8$ and cooling performance of $47 \mathrm{~kW}$ with $\mathrm{EER}=3.4,39$ fan coils and three heat recovery units for the case study n. 3 and 37 fan coils and two heat recovery units in the case study n.4.

For the lighting system, all the existing lamps have been replaced with LED ones and the insertion of a different number of motion sensors in the corridors based on the size of the hotel facilities: for case study n.1 20 motion sensors have been inserted in the corridors and 250 lamps replaced with LED lamps; in case studies n.2 and n.3 35 motion sensors have been installed in the corridors and no replacement of lamps has been necessary because they are already all LED; finally, in the case study n.4, 12 movement sensors have been inserted in the corridors.

To complete the interventions from the plant point of view in each hotel, the system has been integrated with some PV panels, on surfaces of variable size depending on the case between $8 \mathrm{~m}^{2}$ and $150 \mathrm{~m}^{2}$.

\subsection{Results}

With the design solutions adopted, it has been possible to perform a new analysis of the post-intervention thermal loads which revealed significant differences between consumption before and after the proposed interventions.

Case study n.1 Hotel Damaso showed an overall consumption of $119,473 \mathrm{kWh} / \mathrm{y}$ of non-deferrable thermal loads [loads due to lighting (33\%), transport of people or things (2\%), various electrical uses (21\%)], an unchanged annual consumption of $4,526 \mathrm{kWh} / \mathrm{y}$ of deferrable thermal loads and the addition of storable loads equal to 87,220 $\mathrm{kWh} / \mathrm{y}$ of which $10 \%$ for heating, $8 \%$ for cooling, $22 \%$ for the production of domestic hot water and $4 \%$ for mechanical ventilation, which have become storable loads thanks to the electrification of the systems.

Case study n. 2 Hotel Albergo del Senato shows an annual consumption of 205,431 kWh/y of non-deferrable thermal loads (of which $40 \%$ due to lighting, $1 \%$ due to the transport of people or things, $20 \%$ linked to various electrical uses); also in this case the deferrable thermal loads remained unchanged with a quota equal to 4,935 $\mathrm{kWh} / \mathrm{y}$, and the storable load with an annual consumption of $124,957 \mathrm{kWh} / \mathrm{y}$ of which $6 \%$ for heating, $5 \%$ for cooling, $23 \%$ for the production of domestic hot water and $5 \%$ for mechanical ventilation.

Case study n.3, the Hotel Raffaello, has an annual consumption of $112,765 \mathrm{kWh} / \mathrm{y}$ from the point of view of non-deferrable thermal loads [loads divided between lighting (32\%), transport of people or things $(2 \%)$ and various electrical uses (22\%)], as regards the deferrable loads, the annual consumption is equal to $4,274 \mathrm{kWh} / \mathrm{y}$, also in this case unchanged compared to the situation before the interventions while the storable loads equal to $84,202 \mathrm{kWh} / \mathrm{y}$ have taken over, divided into $9 \%$ for heating, $7 \%$ for cooling, $25 \%$ for the production of domestic hot water and $3 \%$ for mechanical ventilation. 
Case study 4, the Albergo Etico, has an annual consumption of $109,417 \mathrm{kWh} / \mathrm{y}$ (of which $39 \%$ for lighting, $2 \%$ for the transport of people or things, $19 \%$ for various electrical uses) from the point of view of non-deferrable thermal loads, of 4,155 kWh/y for deferrable thermal loads and 29,638 kWh/y for storable loads, divided between $9 \%$ for heating, $5 \%$ for cooling, $22 \%$ for the production of domestic hot water and $4 \%$ for mechanical ventilation.

Table 6. Deferrable, non-deferrable and storable loads year consumption for each case study.

\begin{tabular}{lccccc}
\hline & & Case study n.1 & Case study n.2 & Case study n.3 & Case study n.4 \\
\hline Non-deferrable loads & {$[\mathrm{kWh} /$ year $]$} & 119,473 & 205,431 & 112,765 & 109,417 \\
Deferrable loads & {$[\mathrm{kWh} /$ year $]$} & 4,526 & 4,935 & 4,274 & 4,155 \\
Storable loads & {$[\mathrm{kWh} /$ year $]$} & 87,220 & 124,957 & 84,202 & 29,638 \\
& & & & \\
\hline
\end{tabular}
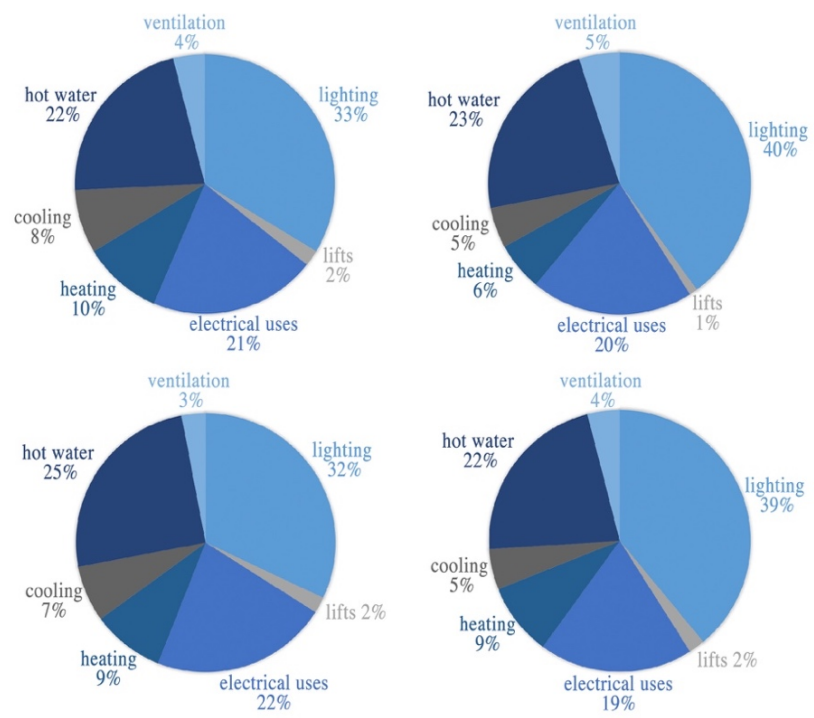

Fig. 5. Graph of the annual consumption of non-deferrable and storable loads for each case study. Percentage share of lighting, transport of people or things, various electrical uses, heating, cooling, domestic hot water production and mechanical ventilation. Top left case study n.1, top right case study n.2, bottom left case study n.3, bottom right case study n.4.

Following the calculation of the thermal loads, a new calculation of primary energy consumption has been carried out in the light of the design solutions chosen for each case study. This calculation has been explained in the following Table 7 (a-d).

Table 7a. Primary energy consumption - intervention proposal for the case study n.1 - Hotel Damaso

\begin{tabular}{ccccccccc}
\hline & & Heating & Cooling & Hot water & Lift & Lighting & Ventilation & Total \\
\hline Renewable & {$[\mathrm{kWh} / \mathrm{y}]$} & 4,093 & 2,245 & 8,847 & 0,792 & 13,732 & 1,717 & 44,630 \\
Fossil & {$[\mathrm{kWh} / \mathrm{y}]$} & 17,033 & 9,111 & 36,971 & 3,301 & 57,173 & 7,262 & 117,648 \\
Total & {$[\mathrm{kWh} / \mathrm{y}]$} & 21,126 & 11,356 & 45,818 & 4,093 & 70,905 & 8,979 & 162,278 \\
$\begin{array}{c}\text { Renewable } \\
\text { fraction }\end{array}$ & $\%$ & $19.4 \%$ & $19.8 \%$ & $19.3 \%$ & $19.4 \%$ & $19.4 \%$ & $19.1 \%$ & $27.5 \%$ \\
\hline
\end{tabular}


Table 7b. Primary energy consumption - intervention proposal for the case study n.2 - Hotel Albergo del Senato

\begin{tabular}{ccccccccc}
\hline & & Heating & Cooling & Hot water & Lift & Lighting & Ventilation & Total \\
\hline Renewable & {$[\mathrm{kWh} / \mathrm{y}]$} & 4,196 & 2,937 & 14,897 & 0,839 & 26,018 & 2,308 & 73,312 \\
Fossil & {$[\mathrm{kWh} / \mathrm{y}]$} & 17,205 & 12,379 & 61,477 & 3,357 & 107,847 & 9,862 & 183,802 \\
Total & {$[\mathrm{kWh} / \mathrm{y}]$} & 21,401 & 15,316 & 76,374 & 4,196 & 133,865 & 12,170 & 257,114 \\
$\begin{array}{c}\text { Renewable } \\
\text { fraction }\end{array}$ & $\%$ & $19.6 \%$ & $19.1 \%$ & $19.5 \%$ & $20 \%$ & $19.4 \%$ & $19 \%$ & $28.5 \%$ \\
\hline
\end{tabular}

Table 7c. Primary energy consumption - intervention proposal for the case study n.3 - Hotel Raffaello

\begin{tabular}{ccccccccc}
\hline & & Heating & Cooling & Hot water & Lift & Lighting & Ventilation & Total \\
\hline Renewable & {$[\mathrm{kWh} / \mathrm{y}]$} & 3,513 & 1,610 & 9,807 & 0,878 & 12,441 & 1,317 & 39,081 \\
Fossil & {$[\mathrm{kWh} / \mathrm{y}]$} & 14,344 & 7,026 & 40,984 & 4,098 & 51,669 & 5,562 & 113,583 \\
Total & {$[\mathrm{kWh} / \mathrm{y}]$} & 17,857 & 8,636 & 50,791 & 4,976 & 64,110 & 6,879 & 152,664 \\
$\begin{array}{c}\text { Renewable } \\
\text { fraction }\end{array}$ & $\%$ & $19.7 \%$ & $18.6 \%$ & $19.3 \%$ & $17.6 \%$ & $19.4 \%$ & $19.1 \%$ & $25.6 \%$ \\
\hline
\end{tabular}

Table 7d. Primary energy consumption - intervention proposal for the case study n.4 - Albergo Etico

\begin{tabular}{ccccccccc}
\hline & & Heating & Cooling & Hot water & Lift & Lighting & Ventilation & Total \\
\hline Renewable & {$[\mathrm{kWh} / \mathrm{y}]$} & 2,510 & 1,373 & 6,072 & 0,538 & 10,820 & 1,087 & 22,400 \\
Fossil & {$[\mathrm{kWh} / \mathrm{y}]$} & 10,361 & 5,778 & 25,391 & 3,301 & 44,955 & 4,634 & 117,648 \\
Total & {$[\mathrm{kWh} / \mathrm{y}]$} & 12,871 & 7,151 & 31,463 & 2,322 & 55,775 & 5,721 & 143,014 \\
$\begin{array}{c}\text { Renewable } \\
\text { fraction }\end{array}$ & $\%$ & $19.5 \%$ & $19.2 \%$ & $19.3 \%$ & $18.8 \%$ & $19.4 \%$ & $19 \%$ & $16.2 \%$ \\
\hline
\end{tabular}

With all the data collected, it has been possible to determine for each case study the global consumption of nonrenewable energy $\left(\mathrm{Ep}_{\mathrm{gl}, \text {,nren }}\right)$, the energy class to which it belongs and the energy performance of the buildings in summer and winter: for case study n.1 Hotel Damaso, $E p_{\text {gl, nren }}$ is equal to $89.1 \mathrm{kWh} / \mathrm{m}^{2} \mathrm{y}$ and the energy class is A3 with a high quality winter and summer performance of the building; for case study n.2 Hotel Albergo del Senato, $E p_{\mathrm{gl}, \text { nren }}$ is equal to $87.6 \mathrm{kWh} / \mathrm{m}^{2} \mathrm{y}$ and the energy class is $\mathrm{A} 3$ with a high quality winter and summer performance of the building; for case study n. 3 Hotel Raffaello, E $p_{g 1, n r e n}$ is equal to $77.6 \mathrm{kWh} / \mathrm{m}^{2} \mathrm{y}$ and the energy class is A3 with a high quality winter and summer performance of the building; for case study n.4 Albergo Etico, E $p_{\text {gl,nren }}$ is equal to $134.7 \mathrm{kWh} / \mathrm{m}^{2} \mathrm{y}$ and the energy class is B with a low-quality and average winter building performance in the summer season.

\subsection{Economic analysis of the interventions}

After the definition of the interventions strategies on the building envelope and on the systems it has been possible to make a rough estimate of the investment costs in order to understand the annual savings regarding the energy consumption and the payback time compared to the interventions for each case study.

An interesting approach has been to evaluate the intervention costs with two different parameters: net of the incentive expenses deriving from the tax deduction ${ }^{2}$ and, secondly, showing how much the percentage of tax deduction affects the reduction of costs as can been seen in Table 8(a-d).

\footnotetext{
${ }^{2}$ Fiscal tax deductions have been evaluated referring to the Legge di Bilancio 2019, promulgated on 30/12/2018 n.145, without taking into account the incentive measures implemented with the D.L. Rilancio n. 34/2020.
} 
Table 8a. Expected cost for the realisation of interventions in the case study n.1 - Hotel Damaso.

\begin{tabular}{lccccc}
\hline \multicolumn{1}{c}{ Intervention } & \multicolumn{2}{c}{ Intervention cost } & $\begin{array}{c}\text { Percentage of fiscal } \\
\text { deduction }\end{array}$ & $\begin{array}{c}\text { Intervention cost with } \\
\text { fiscal deduction }\end{array}$ \\
\hline Building envelope & 91,757 & {$[€]$} & $65 \%$ & 32,115 & {$[€]$} \\
Thermal energy production & 13,274 & {$[€]$} & $65 \%$ & 4,646 & {$[€]$} \\
Heating and Cooling & 22,250 & {$[€]$} & $65 \%$ & 7,788 & {$[€]$} \\
Ventilation & 30,092 & {$[€]$} & $55 \%$ & 31,432 & {$[€]$} \\
Lighting & 850 & {$[€]$} & $0 \%$ & 850 & {$[€]$} \\
PV system & 17,500 & {$[€]$} & $55 \%$ & 7,875 & {$[€]$} \\
\hline TOTAL & 175,723 & {$[€]$} & & 84,706 & {$[€]$} \\
\hline
\end{tabular}

Table 8b. Expected cost for the realisation of interventions in the case study n. 2 - Hotel Albergo del Senato.

\begin{tabular}{lccccc}
\hline \multicolumn{1}{c}{ Intervention } & \multicolumn{2}{c}{ Intervention cost } & $\begin{array}{c}\text { Percentage of fiscal } \\
\text { deduction }\end{array}$ & $\begin{array}{c}\text { Intervention cost with } \\
\text { fiscal deduction }\end{array}$ \\
\hline Building envelope & 105,159 & {$[€]$} & $65 \%$ & 36,806 & {$[€]$} \\
Thermal energy production & 15,266 & {$[€]$} & $65 \%$ & 5,343 & {$[€]$} \\
Heating and Cooling & 39,444 & {$[€]$} & $65 \%$ & 13,806 & {$[€]$} \\
Ventilation & 38,274 & {$[€]$} & $55 \%$ & 17,096 & {$[€]$} \\
Lighting & 196 & {$[€]$} & $0 \%$ & 196 & {$[€]$} \\
PV system & 26,250 & {$[€]$} & $55 \%$ & 11,813 & {$[€]$} \\
\hline TOTAL & 209,338 & {$[€]$} & & 85,060 & {$[€]$} \\
\hline
\end{tabular}

Table 8c. Expected cost for the realisation of interventions in the case study n. 3 - Hotel Raffaello.

\begin{tabular}{lccccc}
\hline \multicolumn{1}{c}{ Intervention } & \multicolumn{2}{c}{ Intervention cost } & $\begin{array}{c}\text { Percentage of fiscal } \\
\text { deduction }\end{array}$ & $\begin{array}{c}\text { Intervention cost with } \\
\text { fiscal deduction }\end{array}$ \\
\hline Building envelope & 84,113 & {$[€]$} & $65 \%$ & 29,440 & {$[€]$} \\
Thermal energy production & 13,174 & {$[€]$} & $65 \%$ & 4,611 & {$[€]$} \\
Heating and Cooling & 20,876 & {$[€]$} & $65 \%$ & 7,307 & {$[€]$} \\
Ventilation & 29,936 & {$[€]$} & $55 \%$ & 13,378 & {$[€]$} \\
Lighting & 4,596 & {$[€]$} & $0 \%$ & 4,596 & {$[€]$} \\
PV system & 8,750 & {$[€]$} & $55 \%$ & 3,938 & {$[€]$} \\
\hline TOTAL & 161,445 & {$[€]$} & & 63,270 & {$[€]$} \\
\hline
\end{tabular}

Table 8d. Expected cost for the realisation of interventions in the case study n.4 - Albergo Etico.

\begin{tabular}{|c|c|c|c|c|c|}
\hline \multirow{2}{*}{$\begin{array}{r}\text { Intervention } \\
\text { Building envelope }\end{array}$} & \multicolumn{2}{|c|}{ Intervention cost } & \multirow{2}{*}{$\begin{array}{c}\begin{array}{c}\text { Percentage of fiscal } \\
\text { deduction }\end{array} \\
65 \%\end{array}$} & \multicolumn{2}{|c|}{$\begin{array}{l}\text { Intervention cost with } \\
\text { fiscal deduction }\end{array}$} \\
\hline & 128,245 & {$[€]$} & & 44,886 & {$[€]$} \\
\hline Thermal energy production & 13,174 & {$[€]$} & $65 \%$ & 4,611 & {$[€]$} \\
\hline Heating and Cooling & 34,387 & {$[€]$} & $65 \%$ & 12,035 & {$[€]$} \\
\hline Ventilation & 14,245 & {$[€]$} & $55 \%$ & 6,410 & {$[€]$} \\
\hline Lighting & 67 & {$[€]$} & $0 \%$ & 67 & {$[€]$} \\
\hline PV system & 17,500 & {$[€]$} & $55 \%$ & 7,875 & {$[€]$} \\
\hline TOTAL & 207,618 & {$[€]$} & & 75,884 & {$[€]$} \\
\hline
\end{tabular}


Following the analysis of the expected costs for the proposed interventions, a reflection has been also made on the payback time on investment which varies substantially if we take into account the total costs borne by the client or the percentage contribution decreased thanks to the deductions. tax. For the Damaso Hotel (case study n.1) the payback time varies from 9 years if the amount is considered in full, to 4 years if, on the other hand, tax deductions are used; for the Hotel Albergo del Senato (case study n.2) the return time varies from 16 to 6 years; for the Hotel Raffaello (case study n.3) from 18 to 7 years while for the Albergo Etico (case study n.4) it varies from 12 to 5 years.

\section{Conclusions}

This research focuses on various aspects. First of all, it proposes a valid approach for the energy refurbishment of buildings which, despite undergoing significant transformations, still maintain their architectural characteristics unchanged in compliance with the historical and aesthetic constraints to which buildings, in the historic centres of cities such as Rome, are linked. The second aspect is the approach aimed at the total unification of the energy vector in electricity, which is no longer fully supplied by the managers but largely self-produced thanks to the integration of the PV system in the roofing of the buildings.

Thanks to these interventions, it has been possible to demonstrate how this operation of total electrification of the buildings leads to a percentage increase in the storable loads, an important reduction in energy consumption and consequent management costs, despite significant changes have been made to the systems, useful for control and improvement of thermo-hygrometric well-being conditions within the four hotels.

Alongside the benefits from an economic and social point of view, it is equally relevant to place on the same level those of an environmental nature that derive from the substantial reduction of $\mathrm{CO}_{2}$ emissions linked to the total electrification of the complex and from the increase in the percentage of clean electricity production from renewable sources. Electricity backed by zero carbon energies involves a clean electrification which is the key to transition cities to a net zero carbon future and to do so it is important to focus on ultra-efficient buildings that combine high performance and low-carbon buildings with electric systems, distributed energy and intelligent management systems (like efficient windows, lighting control systems and other appliance controls).

The primary goal of this research is to prove that the combination of efficiency, clean end-use electrification, active energy management, integrated design and digital technologies all together can significantly reduce existing building energy consumption and emissions and this is the path to follow to decarbonise cities.

\section{References}

[1] Autorità di Regolazione per Energia Reti e Ambiente (ARERA), Stato di utilizzo e di integrazione degli impianti di produzione alimentati dalle fonti rinnovabili e di generazione distribuita - Relazione sullo stato dei servizi, Relazione 321/2020/I/FER, (2020) Availabile online: https://www.arera.it/allegati/docs/20/321-20.pdf (accessed 15 January 2021)

[2] European Parliament and the Council, Directive EU 2018/2001 of the European Parliament and of the Council of 11 December 2018 on the promotion of the use of energy from renewable sources (recast) L328/82, Official Journal of the European Union, EUR-Lex (2018)

[3] European Commission, Energy Roadmap 2050, Publication Office of the European Union, Luxemburg (2012)

[4] European Commission, A Renovation Wave initiative for public and private buildings, (2020). Available online: $\quad$ https://ec.europa.eu/energy/topics/energy-efficiency/energy-efficient-buildings/renovationwave en (accessed on 16 November 2020)

[5] F. Manzano-Agugliaro, M. Taher, A. Zapata-Sierra, A. Juaidi, F.G. Montoya, An overview of research and energy evolution for small hydropower in Europe, Renewable and Sustainable Energy Reviews, 75 (2017)

[6] Istituto Superiore per la Protezione e la Ricerca Ambientale (ISPRA), La produzione di energia elettrica da impianti da fonte rinnovabile in Italia - Rapporto 189/2013. Available online: https://www.isprambiente.gov.it/files/pubblicazioni/rapporti/copy2 of R 189 13.pdf (accessed on 16 November 2020)

[7] Gestione Servizi Energetici, Sviluppo e diffusione delle fonti rinnovabili in Italia e in Europa, (2019). Available online:https://www.gse.it/documenti site/Documenti\%20GSE/Rapporti\%20statistici/GSE\%20\%20Fonti\%20rinnovabili\%20in\%20Italia\%20e\%20in\%20Europa\%20-\%202019.pdf (accessed on 15 
January 2021)

[8] Terna Group, Impianti di generazione (2016).

Available online: https://download.terna.it/terna/0000/0964/25.PDF (accessed on 15 November 2020)

[9] Sistema Statistico Nazionale e Terna Group, 2019, Dati statistici sull'energia elettrica in Italia. Available online: https://download.terna.it/terna/Annuario\%20Statistico\%202018 8d7595e944c2546.pdf (accessed on 16 January 2021)

[10] F. Mancini, G.L. Basso, How climate change affects the building energy consumptions due to cooling, heating, and electricity demands of Italian residential sector, Energies, 13(2), 410 (2020)

[11] Belicini, L., Toso, F. - ENEA, Ministero dello Sviluppo Economico, Edifici tipo, indici di benchmark di consumo per tipologie di edificio ad uso alberghiero, applicabilità di tecnologie innovative nei diversi climi italiani - Report Ricerca di Sistema Elettrico RdS/2010/189 (2010)

[12] Intergovernmental Panel on Climate Change (IPCC), Special Report on Global Warming of $1.5{ }^{\circ} \mathrm{C}$, Switzerland (2018)

[13] Intergovernmental Panel on Climate Change (IPCC), IPCC Climate Change and Land, Switzerland (2019)

[14] World Economic Forum (WEF), Accelerating access to sustainable energy: a key priority in energy transition, Global Future Council on Energy 2018-2019, Switzerland (2019)

[15] F. Mancini, S. Romano, G.L. Basso, J. Cimaglia, L. De Santoli, How the Italian residential sector could contribute to load flexibility in demand response activities: A methodology for residential clustering and developing a flexibility strategy, Energies, 13(13), 3359 (2020)

[16] Istat, Rapporto sul turismo 2019, (2020). Available at: https://www.istat.it/it/files//2020/12/C19.pdf (accessed on 16 February 2021)

[17] Agenzia Nazionale del Turismo Italia (Enit), Piano Annuale del turismo italiano 2019, (2020). Available at:

https://www.enit.it/wwwenit/images/amministrazionetrasparenteepe/disposizionigenerali/Piano\%20Annu ale\%202019.pdf (accessed on 16 February 2021)

[18] Aprile, M. - ENEA, Ministero dello Sviluppo Economico, Caratterizzazione energetica del settore alberghiero in Italia - Report Ricerca di Sistema Elettrico RSE/2009/162, (2009)

[19] Enesco, Risparmio Energetico nel settore Alberghiero (2019)

[20] Bonafaccia, F., Griesi, A. (Federazione delle Associazioni Italiane Alberghi e Turismo), Incentivi per la riqualificazione delle strutture ricettive - settima edizione, Edizioni ISTA, Roma (2019)

[21] Dipartimento per lo sviluppo e la competitività del territorio, Presidenza del Consiglio dei Ministri, DPCM 21/10/2008 - Definizione delle tipologie dei servizi forniti dalle imprese turistiche nell'ambito dell'armonizzazione della classificazione alberghiera, (2009). Available at: http://www.ontit.it/opencms/export/sites/default/ont/it/documenti/archivio/files/ONT 2008-10-

21_01424.pdf

[22] Spitler, J.D., American Society of Heating and Refrigerating and Air-Conditioning Engineers, Load Calculation Applications Manual. Vol. Second edition. I-P edition. Atlanta, GA (2014)

[23] Abasnezhad, S., Soltani, N., Markarian., E., Fakhim, H.A., Khezerloo, H., Impact of building design parameters precision on heating and cooling load calculations, Environmental Progress \& Sustainable Energy, 38(2), 741-749 (2019)

[24] P. Rădan, V. Cenuşă, F. Alexe, E. Arion and A. Adam, Increasing energy efficiency of a combined head and power plant using the heat storage, 2017 International Conference on ENERGY and ENVIRONMENT (CIEM), 515-519, (2017) 